\title{
Differential effects of curcumin on vasoactive factors in the diabetic
} rat heart

\author{
Hana Farhangkhoee ${ }^{1}$, Zia A Khan ${ }^{1,2}$, Shali Chen ${ }^{1}$ and Subrata Chakrabarti*1
}

Address: ${ }^{1}$ Department of Pathology, The University of Western Ontario, London, Ontario N6A 5C1, Canada and ${ }^{2}$ Vascular Biology Program and Department of Surgery, Children's Hospital Boston, Harvard Medical School, MA 02115, USA

Email: Hana Farhangkhoee - hfarhang@uwo.ca; Zia A Khan - zia.khan@childrens.harvad.edu; Shali Chen - schen4@uwo.ca; Subrata Chakrabarti* - subrata.chakrabarti@schulich.uwo.ca

* Corresponding author

Published: 18 July 2006

Nutrition \& Metabolism 2006, 3:27 doi:10.1 186/1743-7075-3-27
Received: 24 April 2006

Accepted: 18 July 2006

This article is available from: http://www.nutritionandmetabolism.com/content/3/1/27

(c) 2006 Farhangkhoee et al; licensee BioMed Central Ltd.

This is an Open Access article distributed under the terms of the Creative Commons Attribution License (http://creativecommons.org/licenses/by/2.0), which permits unrestricted use, distribution, and reproduction in any medium, provided the original work is properly cited.

\begin{abstract}
Background: Increased oxidative stress has been associated with the pathogenesis of chronic diabetic complications, including cardiomyopathy. Recent studies indicate that curcumin, a potent antioxidant, may be beneficial in preventing diabetes-induced oxidative stress and subsequent secondary complications. We have investigated the effects of curcumin on the nitric oxide (NO) pathway in cardiac tissues and cultured cells.

Methods: Streptozotocin-induced diabetic rats were treated with curcumin for a period of one month. Heart tissues were then analyzed for endothelial NO synthase (eNOS) and inducible NO synthase (iNOS) mRNA expression. Oxidative protein and DNA damage were assessed by immunohistochemical analysis of nitrotyrosine and 8-hydroxy-2'-deoxyguanosine (8-OHdG). Heart tissues were further subjected to endothelin-I (ET-I) mRNA expression. In order to further characterize the effects of curcumin, we assayed microvascular endothelial cells (MVECs). Cultured MVECs, exposed either to glucose or glucose and varying concentrations of curcumin, were assessed for alterations of NOS expression and activation of nuclear factor- $\kappa B$ (NF-KB) and activating protein-I (AP-I). Oxidative stress and ET-I expression levels were also assayed.
\end{abstract}

Results: Our results indicate that one month of diabetes causes an upregulation of both eNOS and iNOS mRNA levels, and nitrotyrosine and 8-OHdG immunoreactivity in the heart. Treatment of diabetic rats with curcumin reduced eNOS and iNOS levels in association with reduced oxidative DNA and protein damage. Interestingly, curcumin further increased vasoconstrictor ET$I$ in the heart. Exposure of MVECs to high glucose increased both eNOS and iNOS levels and oxidative stress. Curcumin prevented NOS alteration and oxidative stress in a dose-dependent manner which was mediated by nuclear factor- $\mathrm{KB}$ and activating protein-I. Exposure to curcumin also increased ET-I levels in the MVECs.

Conclusion: Our studies indicate the differential effects of curcumin in vasoactive factor expression in the heart and indicate the importance of tissue microenvironment in the treatment of diabetic complications. 


\section{Background}

Nearly $40 \%$ of diabetic patients develop secondary complications [1-3]. These complications arise primarily due to sustained hyperglycemia $[4,5]$. Among the vast array of problems associated with long-standing diabetes, cardiovascular complications, including diabetic cardiomyopathy, have been clearly documented as detrimental and as one of the leading causes of mortality [1-3]. Over the years, research has identified some pathological mechanisms underlying diabetic complications [6-9]. One of the purposed mechanisms is increased oxidative stress via augmentation of reactive oxygen species (ROS) [6-9].

An interesting pathway suggested to be involved in augmenting oxidative stress is the nitric oxide (NO) pathway $[10,11]$. NO is produced by a set of three nitric oxide synthase (NOS) isozymes: endothelial NOS (eNOS), inducible NOS (iNOS), and neuronal NOS (nNOS) [12,13]. These enzymes convert L-arginine to L-citrulline, leading to the generation of the free radical NO $[12,13]$. NO is very reactive and is readily sequestered by superoxide anions to form peroxynitrite. Peroxynitrite has been shown to damage proteins by modifying the tyrosine residues $[14,15]$. Many studies have shown that eNOS and iNOS are important players in the pathogenesis of diabetic cardiovascular complications [8,16-18]. Our previous studies indicate that diabetes leads to increased eNOS and iNOS levels in the heart, whereas the amount of NO remains unaltered [18]. It is plausible that NO is quickly scavenged by free radicals such as superoxide anions, producing peroxynitrite.

Curcumin, the active component in Tumeric Rhizomes (Curcuma Long Linn), was originally used in tradition Indian medicine over 3000 years ago [19]. Several studies have indicated a beneficial role of curcumin in terms of antioxidant, anti-tumourgenic, and anti-inflammatory property [20]. A recent study showed that curcumintreated diabetic rats had lower blood glucose and glycated hemoglobin levels, in association with lower oxidative stress [21]. Furthermore, treatment with curcumin has been shown to reduce ROS levels in cells isolated from diabetic patients [22]. It has been suggested that curcumin may mediate some of the effects by partial inhibition of

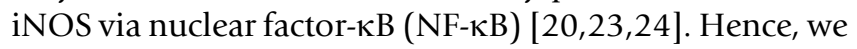
investigated the role of curcumin on diabetes-induced vasoactive factor alteration including $\mathrm{NO}$ to elucidate the possible mechanisms underlying the antioxidant activity. We have further examined the effect of curcumin in cultured endothelial cells.

\section{Methods}

\section{Animal model of chronic diabetes}

Male Sprague-Dawley rats (Charles River Canada Ltd., QC Canada), weighing approximately 200-250 g, were ran- domly divided into three groups $(n=6)$ : controls $(\mathrm{CO})$, diabetic animals (DM), and diabetic animals treated with curcumin (DM-C). Diabetes was induced by a single intravenous injection of streptozotocin (STZ; $65 \mathrm{mg} / \mathrm{kg}$ in citrate buffer, $\mathrm{pH}=5.6)[25,26]$, while the control animals received the same volume of citrate buffer. The use of STZ to induce diabetes provides an animal model of type 1 diabetes, as the drug causes $\beta$-islet cell apoptosis. Curcumin was administered via intraperitoneal injection (150 $\mathrm{mg} / \mathrm{kg}$; Sigma-Aldrich, ON Canada) $[27,28]$. The rats were monitored daily for ketonuria and were given small doses of insulin $(0.1-3 \mathrm{U})$ to prevent ketosis. After 4 weeks of treatment, animals were sacrificed and heart tissues were snap-frozen in liquid nitrogen for gene expression analysis and embedded in paraffin for immunohistochemical analysis. Clinical monitoring of the animals was also performed to evaluate body weight and blood glucose concentrations. All animals were cared for according to the Guiding Principle in the Care and Use of Animals. All experiments were approved by the University of Western Ontario Council on Animal Care Committee.

\section{Endothelial cells cultures}

Human microvascular endothelial cells (HMECs; Clonetics, MD USA) were cultured at 2500 cells $/ \mathrm{cm}^{2}$ in endothelial growth medium (Clonetics) as previously described [29]. Cells were culture in $5 \mathrm{mM}$ glucose (low glucose control; $\mathrm{CO}$ ) and $25 \mathrm{mM}$ glucose (high glucose; HG). In addition, cells cultured in HG were treated with varying concentrations of curcumin $(0.1,10$, and $100 \mu \mathrm{M}$; HG-C) $[30,31]$. After 24 hours of treatment, RNA was extracted and subjected to Real-time RT-PCR. For subsequent analyses, cells were treated with empirically determined curcumin concentration.

\section{RNA extraction and Real Time RT-PCR}

RNA was isolated from heart tissues and cultured ECs as described previously $[18,32]$. cDNA was synthesized with $3 \mu \mathrm{g}$ of total RNA. The mRNA levels of eNOS, iNOS, and ET-1 were quantified using the LightCycler ${ }^{\mathrm{TM}}$ (Roche Diagnostics Canada, QC Canada) [18,32]. In each reaction tube the following reagents were added for a final volume of $20 \mathrm{uL}: 10 \mu \mathrm{L}$ of LC DNA Master SYBR Green 1 (Roche Diagnostic Canada), $1.6 \mu \mathrm{L}$ of $25 \mathrm{mM}$ of $\mathrm{MgCl}_{2}, 1 \mu \mathrm{L}$ each of $10 \mathrm{mM}$ forward and reverse primers (Table 1), $5.4 \mu \mathrm{L}$ of $\mathrm{H}_{2} \mathrm{O}$, and $1 \mu \mathrm{L}$ of cDNA. PCR amplification protocols were optimized for ideal conditions as described previously $[18,32]$. For the assessment of early oxidative stress in cultured ECs $[18,29,33]$, heme oxygenase-1 and -2 (HO-1, HO-2) were also determined.

\section{Immunohistochemistry}

Heart tissues were analyzed for nitrotyrosine, an oxidative protein damage marker, and 8-Hydrox-2'-deoxy Guanosine (8-OHdG), an oxidative DNA damage marker [18]. 
Table I: Primer sequences and PCR parameters

\begin{tabular}{|c|c|c|c|}
\hline Gene & Primers $\left(5^{\prime} \rightarrow 3^{\prime}\right)$ & Temperature & \\
\hline Rat eNOS & $\begin{array}{l}\text { GCAAGACCGATTACACGACA } \\
\text { GTCCTCAGGAGGTCTTGCAC }\end{array}$ & $\begin{array}{l}\text { Denaturation } \\
\text { Annealing } \\
\text { Extension } \\
\text { Signal }\end{array}$ & $\begin{array}{l}95^{\circ} \mathrm{C}-0 \mathrm{sec} \\
57^{\circ} \mathrm{C}-5 \mathrm{sec} \\
72^{\circ} \mathrm{C}-10 \mathrm{sec} \\
85^{\circ} \mathrm{C}-1 \mathrm{sec}\end{array}$ \\
\hline Human eNOS [42] & $\begin{array}{l}\text { CCTCCAGGAAGGAGCAAAC } \\
\text { TCCTGAGAGAGAGGCAAGAGGA }\end{array}$ & $\begin{array}{l}\text { Denaturation } \\
\text { Annealing } \\
\text { Extension } \\
\text { Signal }\end{array}$ & $\begin{array}{l}95^{\circ} \mathrm{C}-0 \mathrm{sec} \\
55^{\circ} \mathrm{C}-5 \mathrm{sec} \\
72^{\circ} \mathrm{C}-8 \mathrm{sec} \\
81^{\circ} \mathrm{C}-1 \mathrm{sec}\end{array}$ \\
\hline Rat iNOS & $\begin{array}{l}\text { ATGGAACAGTATAAGCGAAACACC } \\
\text { GTTTCCGGTCGATGTCATGAGCAAAGG }\end{array}$ & $\begin{array}{l}\text { Denaturation } \\
\text { Annealing } \\
\text { Extension } \\
\text { Signal }\end{array}$ & $\begin{array}{l}95^{\circ} \mathrm{C}-0 \mathrm{sec} \\
57^{\circ} \mathrm{C}-5 \mathrm{sec} \\
72^{\circ} \mathrm{C}-10 \mathrm{sec} \\
83^{\circ} \mathrm{C}-1 \mathrm{sec}\end{array}$ \\
\hline Human iNOS [42] & $\begin{array}{l}\text { CCCCATCAAGCCCTTTACTT } \\
\text { CACСTCCTGGTGGTCACTT }\end{array}$ & $\begin{array}{l}\text { Denaturation } \\
\text { Annealing } \\
\text { Extension } \\
\text { Signal }\end{array}$ & $\begin{array}{l}95^{\circ} \mathrm{C}-0 \mathrm{sec} \\
55^{\circ} \mathrm{C}-5 \mathrm{sec} \\
72^{\circ} \mathrm{C}-8 \mathrm{sec} \\
81^{\circ} \mathrm{C}-1 \mathrm{sec}\end{array}$ \\
\hline Rat ET-I & $\begin{array}{l}\text { GCTCCTGCTCCTCCTTGATG } \\
\text { CTCGCTCTATGTAAGTCATGG }\end{array}$ & $\begin{array}{l}\text { Denaturation } \\
\text { Annealing } \\
\text { Extension } \\
\text { Signal }\end{array}$ & $\begin{array}{l}95^{\circ} \mathrm{C}-0 \mathrm{sec} \\
55^{\circ} \mathrm{C}-5 \mathrm{sec} \\
72^{\circ} \mathrm{C}-20 \mathrm{sec} \\
84^{\circ} \mathrm{C}-1 \mathrm{sec}\end{array}$ \\
\hline Human ET-I & $\begin{array}{l}\text { AAGCCCTCCAGAGAGCGTTAT } \\
\text { CCGAAGGTCTGTCACCAATGT } \\
\text { 6FAM-TGACCCACAACCGAG-MGBNFQ }\end{array}$ & $\begin{array}{l}\text { Denaturation } \\
\text { Annealing } \\
\text { Extension } \\
\text { Signal }\end{array}$ & $\begin{array}{l}95^{\circ} \mathrm{C}-0 \mathrm{sec} \\
55^{\circ} \mathrm{C}-5 \mathrm{sec} \\
72^{\circ} \mathrm{C}-4 \mathrm{sec} \\
72^{\circ} \mathrm{C}-1 \mathrm{sec}\end{array}$ \\
\hline Human HO-I [43] & $\begin{array}{l}\text { TGATAGAAGAGGCCAAGA } \\
\text { TTTCCAGACAGAGGGACA }\end{array}$ & $\begin{array}{l}\text { Denaturation } \\
\text { Annealing } \\
\text { Extension } \\
\text { Signal }\end{array}$ & $\begin{array}{l}95^{\circ} \mathrm{C}-0 \mathrm{sec} \\
50^{\circ} \mathrm{C}-10 \mathrm{sec} \\
72^{\circ} \mathrm{C}-17 \mathrm{sec} \\
84^{\circ} \mathrm{C}-1 \mathrm{sec}\end{array}$ \\
\hline Human HO-2 [43] & $\begin{array}{l}\text { TGGAGCGCAACAAGGACCAT } \\
\text { CCGGTAGAGCTGCTTGAACT }\end{array}$ & $\begin{array}{l}\text { Denaturation } \\
\text { Annealing } \\
\text { Extension } \\
\text { Signal }\end{array}$ & $\begin{array}{l}95^{\circ} \mathrm{C}-0 \mathrm{sec} \\
50^{\circ} \mathrm{C}-10 \mathrm{sec} \\
72^{\circ} \mathrm{C}-17 \mathrm{sec} \\
84^{\circ} \mathrm{C}-1 \mathrm{sec}\end{array}$ \\
\hline$\beta$-actin & $\begin{array}{l}\text { CCTCTATGCCAACACAGTGC } \\
\text { CATCGTACTCCTGCTTGCTG }\end{array}$ & $\begin{array}{l}\text { Denaturation } \\
\text { Annealing } \\
\text { Extension } \\
\text { Signal }\end{array}$ & $\begin{array}{l}95^{\circ} \mathrm{C}-0 \mathrm{sec} \\
58^{\circ} \mathrm{C}-5 \mathrm{sec} \\
72^{\circ} \mathrm{C}-8 \mathrm{sec} \\
83^{\circ} \mathrm{C}-1 \mathrm{sec}\end{array}$ \\
\hline
\end{tabular}

* Initial denaturation was carried out at $95^{\circ} \mathrm{C}$ for 3 minutes.

Paraffin-embedded heart tissues were sectioned $(5 \mu \mathrm{m})$ and transferred to positively charged slides. Slides were stained using the Vectastain Elite Kit (Vector Laboratories, ON Canada) and monoclonal antibodies for nitrotyrosine (1:100, Caymen Chemicals, MI USA) and 8-OHdG (1:50, Japan Institute for the Control of Aging, Fukuroi, Japan). The chromagen, 3'-3' diaminobezine (DAB, Sigma-Aldrich Canada Ltd) was used to detect the oxidative protein and DNA damage levels. Staining with nonimmune rabbit serum instead of primary antibodies was used as negative controls. Ten random fields were examined by two investigators unaware of the experimental treatment. Nitrotyrosine staining was evaluating by measuring the relative cytoplasmic staining intensity, while 8OHdG was assessed by counting the number of positive cardiomyocytes.

\section{Electrophoretic mobility shift assay}

Electrophoretic mobility shift assay (EMSA) was performed to assess activation of transcription factors, NF- $\mathrm{KB}$ and activating protein-1 (AP-1), as described previously $[29,34]$.

\section{Statistical analysis}

The data are expressed at mean \pm S.E.M. and were analyzed by ANOVA followed by student's t-test. Statistical differences were considered when $\mathrm{p}<0.05$.

\section{Results}

\section{Clinical monitoring of the diabetic animals}

Animals were monitored for body weight gain and blood glucose levels to assess diabetic dysmetabolism. Diabetic animals exhibited decreased body weight gain and increased blood glucose levels as compared to non-dia- 
Table 2: Clinical monitoring of animals

\begin{tabular}{lll}
\hline Treatment & Body Weight Gain (gms) & Glucose (mM) \\
\hline CO & $510 \pm 20$ & $4.2 \pm 0.2$ \\
DM & $435 \pm 25^{*}$ & $22.1 \pm 2.5^{*}$ \\
DM-C & $413 \pm 2^{*}$ & $19.8 \pm 1.4^{*}$ \\
\hline
\end{tabular}

$*_{p}<0.05$ compared to $\mathrm{CO}$

betic controls (Table 2). Curcumin did not have any effect on these parameters.

\section{Diabetes upregulates NOS and ET-I levels in the heart with increased oxidative stress}

Heart tissues from diabetic animals exhibited increased eNOS and iNOS mRNA levels as compared to control rats (Figure 1A). ET-1 mRNA levels were also increased in the diabetic animals (Figure 1B). To determine whether alteration of NOS expression was associated with oxidative stress, we assayed for oxidative protein and DNA damage. Immunohistochemical analysis showed that diabetes caused increased nitrotyrosine immunoreactivity (Figure 2A). In addition, heart tissues from diabetic animals exhibited increased levels of 8-OHdG (Figure 2B).

\section{Curcumin prevents diabetes-induced NOS alteration and oxidative damage}

Treatment of diabetic animals with curcumin prevented eNOS and iNOS mRNA upregulation (Figure 1A). Interestingly, curcumin caused a greater increase in diabetesinduced ET-1 expression in the heart (Figure 1B). We next determined whether the target organs of diabetic complications also exhibited increased ET-1 expression upon curcumin treatment. Analysis of retina and kidney samples revealed that ET-1 was normalized as compared to untreated diabetic animals (data not shown). The decrease in eNOS and iNOS levels was associated with reduced nitrotyrosine staining (Figure 2A), indicating decreased NO scavenging and oxidative protein damage. In addition, curcumin-treated diabetic animals showed decreased oxidative DNA damage (Figure 2B).

\section{Effect of curcumin on high glucose-induced eNOS and iNOS expression and oxidative stress in ECs}

In order to investigate the mechanisms of curcumin-mediated downregulation of NOS and oxidative stress, we assayed microvascular ECs. Exposure of ECs to high glucose levels $(25 \mathrm{mmol} / \mathrm{L})$ increased both eNOS and iNOS mRNA levels (Figure 3A). Treatment of cells exposed to 25 $\mathrm{mM}$ glucose to varying levels of curcumin prevented both eNOS and iNOS expression (Figure 3B). Such changes were mediated by decreased activation of redox-sensitive transcription factors, NF- $\kappa B$ and AP-1 (Figure 3C and 3D). To determine whether curcumin alters ET-1 levels in the ECs, we treated the cells with the maximal concentration

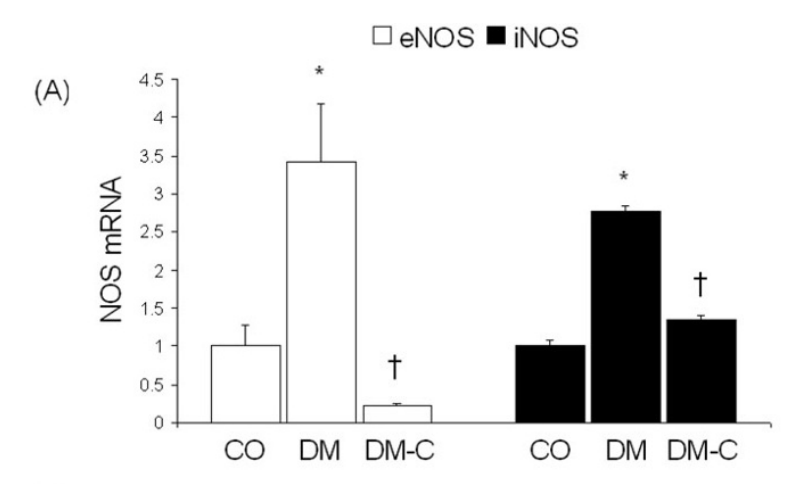

(B)

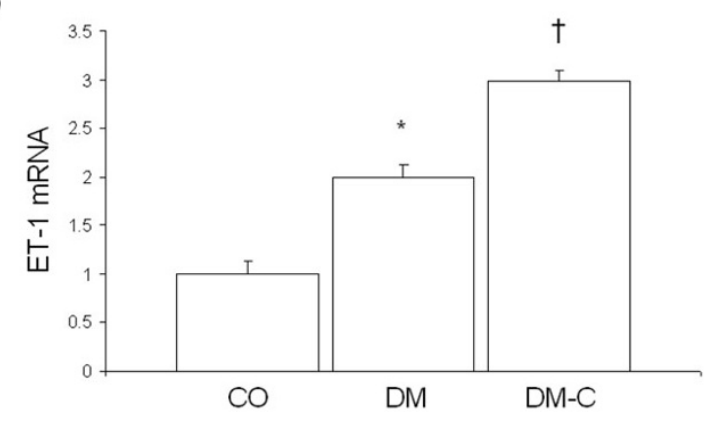

Figure I

Effect of curcumin on diabetes-induced vasoactive factor expression, showing real time RT-PCR analysis of (A) NOS, and (B) ET-I transcript levels in the heart tissues [CO, control; DM, diabetics; DM-C, diabetics treated with $150 \mathrm{mg} / \mathrm{kg} /$ $\mathrm{d}$ curcumin; $*_{\mathrm{p}}<0.05$ compared to $\mathrm{CO} ; \dagger_{\mathrm{p}}<0.05$ compared to DM; $n=4$ /group].

of curcumin $(100 \mu \mathrm{M})$ and assayed for ET-1 transcript level by real time RT-PCR. Our results indicate that curcumin potentiated high glucose-induced ET-1 levels in the ECs (Figure 4A).

In order to assess whether curcumin prevents high glucose-induced oxidative stress, we employed the early molecular marker of oxidative damage, HO-1 and HO-2. Our results show that glucose-induced HO-1 and HO-2 expression is normalized by pre-treatment with curcumin (Figure 4B).

\section{Discussion}

In the present study, we showed that diabetes causes an increase in eNOS and iNOS mRNA levels in the cardiac tissues, in association with increased oxidative protein and DNA damage. Treatment of diabetic animals with curcumin prevents diabetes-induced eNOS/iNOS upregulation and oxidative stress. We also report, for the first time, that curcumin potentiates diabetes-induced ET-1 mRNA levels in the heart. Furthermore, the mechanism of 
(A)
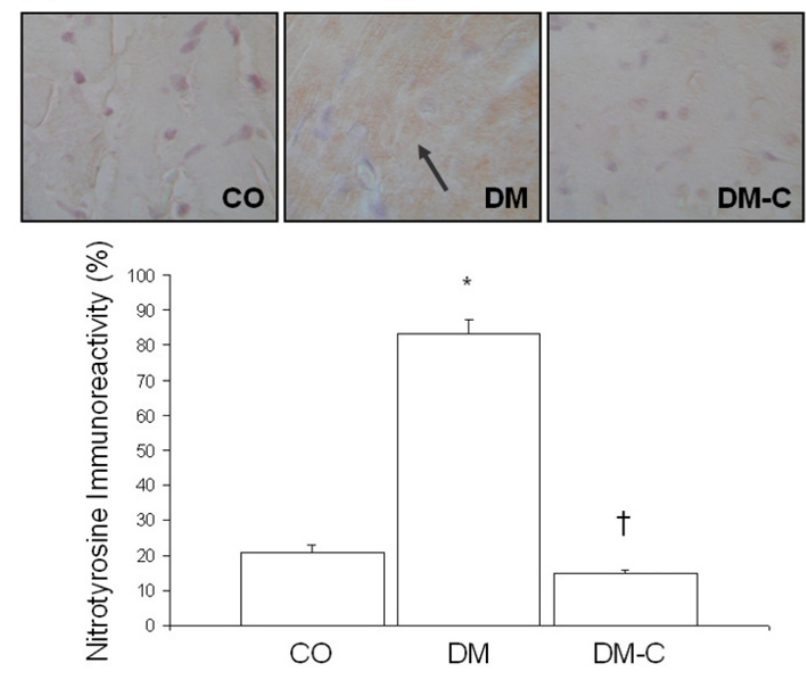

(B)
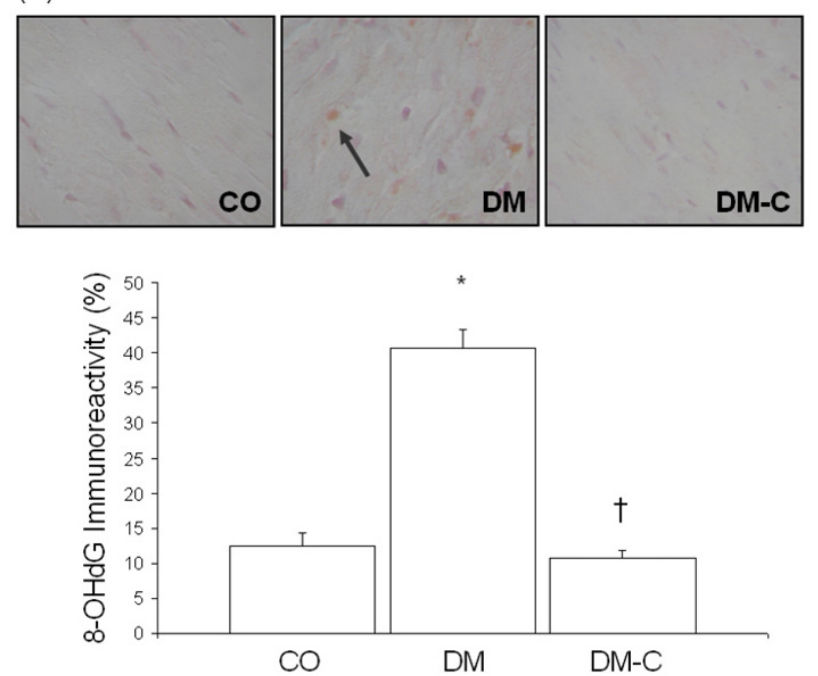

Figure 2

Diabetes-induced oxidative stress as assessed by $(A)$ nitrotyrosine, and (B) 8-OHdG staining. Curcumin decreased the level of oxidative DNA and protein damage [Original magnification X400; * $\mathrm{p}<0.05$ compared to $\mathrm{CO}$; $\mathrm{\dagger p}<0.05 \mathrm{com}-$ pared to DM].

NOS alteration by curcumin involves activation of NF- $\kappa B$ and AP-1.

Over the past several decades, researchers have provided substantial evidence that oxidative stress is augmented in diabetic complications, including cardiomyopathy $[35,36]$. Several pathways have been shown to augment oxidative stress during long-standing diabetes $[8,9]$. The mechanisms of increased oxidative stress in diabetes are multifactorial [6-9]. One mechanism is by increasing glucose flux through the aldose reductase pathway, resulting in alterations of the cofactors required for several important antioxidant enzymes. Another mechanisms is an increased flux through the mitochondrial electron transport chain; thus, leading to the production of a superoxide anions. Activation of protein kinase $\mathrm{C}$ has also been documented as increasing oxidative stress since such activation leads to altered NADPH oxidase function. Other pathways include the generation of advanced glycated end (AGE) products and glucose auto-oxidation. The NO pathway has also been implemented in oxidative stress during diabetic complications $[8,9,37]$. We have previously shown that the levels of NO in long-standing diabetes are not changed, however, NOS mRNA expression is upregulated [18]. This suggests that early increased NO could be sequestered by scavenger molecules such as superoxide anions and subsequently damage proteins/ DNA and increase oxidative stress. Our results of the present study do support this notion. We have shown that diabetes leads to increased eNOS and iNOS expression in association with augmented peroxynitrite/8OHdG levels.

Curcumin, a potent antioxidant and anti-inflammatory compound, has been shown to mediate many biological affects such as downregulation of NOS [38-40]. A recent study showed that treating lipopolysaccharide-activated murine macrophages with curcumin reduced the levels of iNOS mRNA and protein [39]. The researchers provided support that the reduction in iNOS was attributed to inhibition of redox-active transcription factors required for iNOS induction. Curcumin may also directly lead to reduced NO oxidation by sequestering the reaction intermediate, nitrogen dioxide [41]. Our results confirm these findings in the heart and show that curcumin reduces NO scavenging as assessed by lower nitrotyrosine staining levels. We have also shown that both eNOS and iNOS mRNA levels are reduced in curcumin-treated diabetic cardiac tissues. Moreover, we have provided first evidence of a similar effect of curcumin in cultured ECs. These changes were associated with reduced activation of NF- $\kappa \mathrm{B}$ and AP-1.

One other interesting finding of the study is the effect of curcumin on ET-1 expression in the heart as well as cultured ECs. ET-1 was found to be further increased in curcumin-treated diabetic animals and ECs exposed to high glucose levels. It is possible that curcumin may have a differential effect on the vasoactive factors. Our results show that curcumin decreases eNOS/iNOS levels in the heart and cultured ECs but increases ET-1 levels. The mechanism of such action and potential significance remains to be determined. The differential effects of curcumin on eNOS/iNOS and ET-1 may be due to the activation of different transcriptional regulators. Another possible explanation may be that the downregulation of eNOS/iNOS could have a secondary effect on ET-1. It is also plausible that such an alteration may represent the importance of 
(A)

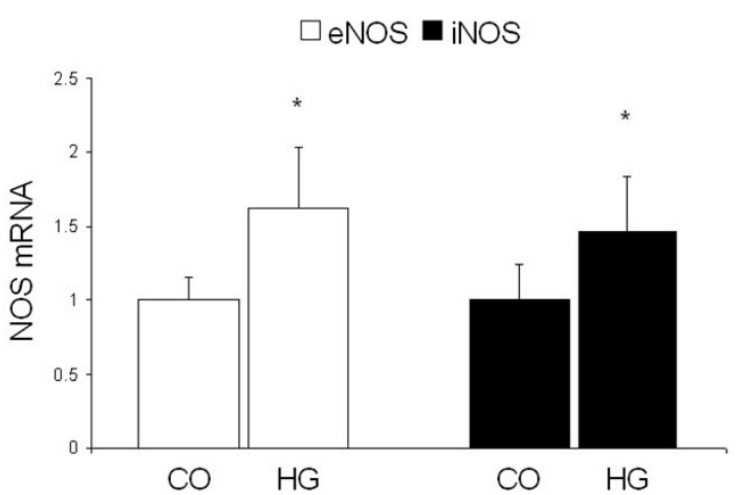

(C)

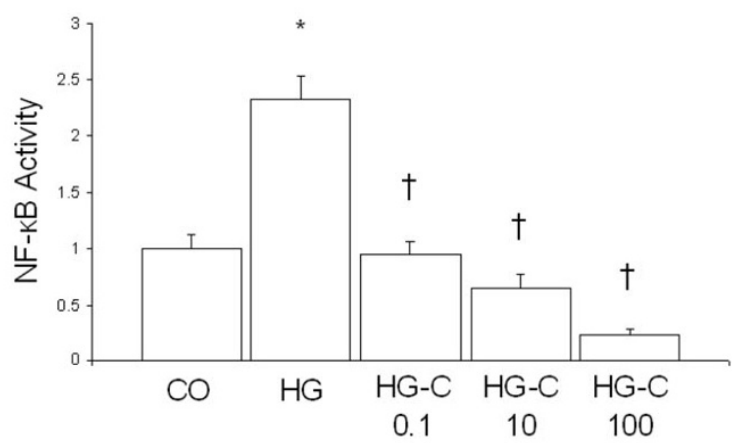

(B)

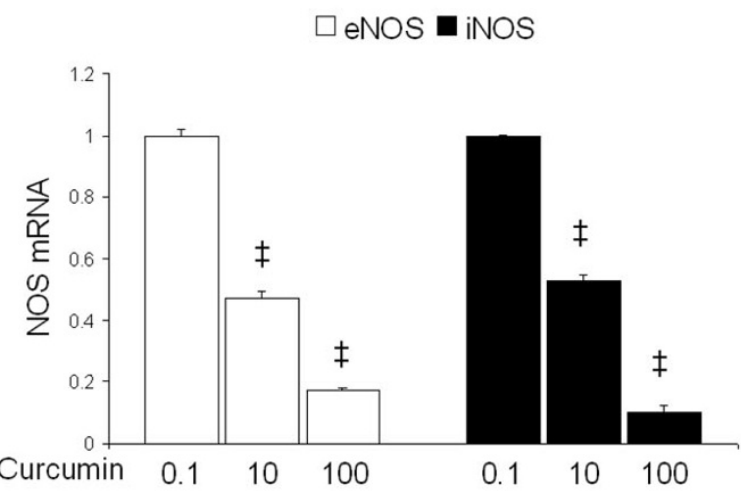

(D)

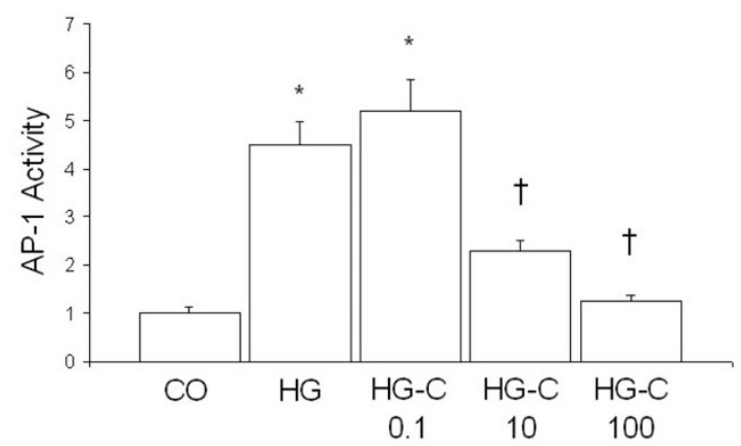

\section{Figure 3}

Effect of high glucose levels (A) and curcumin (B) on NOS mRNA levels and transcription factor activity in ECs. ECs exposed to $25 \mathrm{mM}$ glucose were treated with varying curcumin concentrations $(0.1,10$, and $100 \mu \mathrm{M}$ in $\mathrm{B})$ and assayed for eNOS and iNOS expression (A and $B$ ) and transcription factor activity ( $C$ and $D)$ [CO, 5 mM glucose; HG, 25 mM glucose; HG-C, HG + curcumin $(\mu \mathrm{M}) ;{ }^{*} \mathrm{p}<0.05$ compared to CO; $\nmid \mathrm{p}<0.05$ compared to HG; $\neq \mathrm{p}<0.05$ compared to $\left.0.1 \mu \mathrm{M}\right]$.

tissue microenvironment and bystander cells. In support of such a notion, our studies indicate that curcumin decreases ET-1 levels in the kidneys and the retina (data not shown). Further studies are necessary to elucidate whether such differences represent the different molecular aberrations in the target organs of chronic diabetic complications.

\section{Conclusion}

Our results support the findings that curcumin prevents diabetes-induced oxidative protein and DNA damage, in association with decreasing NOS levels. Our findings also suggest that the use of curcumin in novel therapeutic modalities should be approached with caution, as curcumin may augment vasoactive peptide ET-1 and lead to vascular dysfunction in diabetes.

\section{Competing interests}

The author(s) declare that they have no competing interests.

\section{Authors' contributions}

HF conducted the majority of the in vitro and in vivo experiments, including helping maintain the diabetic animals. HF also assisted in drafting the manuscript and preparing it for publication.

ZAK maintained the diabetic animals and helped to interpret the in vivo and in vitro data. ZAK also helped draft the manuscript and revised it critically for intellectual content.

SC helped with conducting the molecular techniques and assisted in interpreting the results.

$\mathrm{SC}^{*}$ assisted in the experimental design, revised the manuscript critically for intellectual content, and gave the final approval for the manuscript to be submitted for publication. In addition, all the experiments were conducted under his grant approval. 
(A)

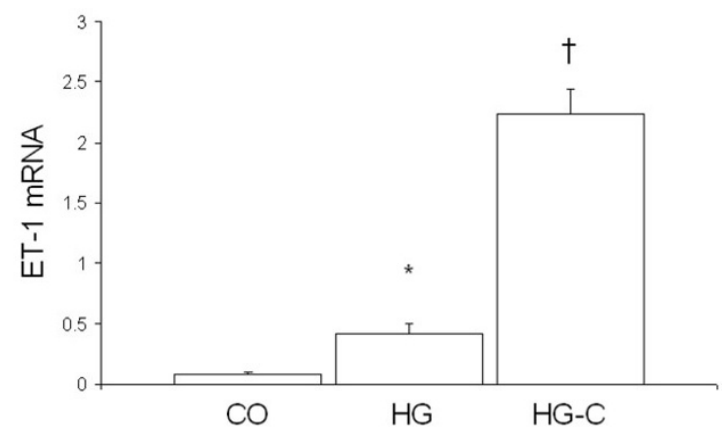

(B)

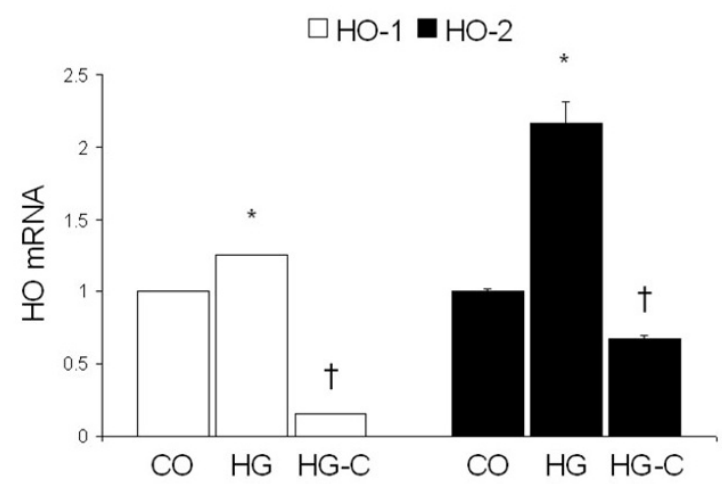

Figure 4

ET-I (A) and HO (B) expression in ECs cultured with $25 \mathrm{mM}$ glucose and $100 \mu \mathrm{M}$ curcumin as assessed by real time RTPCR [HG-C, HG + $100 \mu M$ curcumin; ${ }^{*} \mathrm{p}<0.05$ compared to $\mathrm{CO} ; \mathrm{\dagger p}<0.05$ compared to HG].

\section{Acknowledgements}

The authors acknowledge grant supports from the Canadian Diabetes Association in honour of the late Glenn W. Liebrock, the Canadian Institutes of Health Research, and the Heart and Stroke Foundation of Ontario.

\section{References}

I. Garcia MJ, McNamara PM, Gordon T, Kannel WB: Morbidity and mortality in diabetics in the Framingham population. Sixteen year follow-up study. Diabetes 1974, 23(2): 105-III.

2. Role of cardiovascular risk factors in prevention and treatment of macrovascular disease in diabetes. American Diabetes Association. Diabetes Care 1989, I 2(8):573-579.

3. Hayat SA, Patel B, Khattar RS, Malik RA: Diabetic cardiomyopathy: mechanisms, diagnosis and treatment. Clin Sci (Lond) 2004, 107(6):539-557.

4. The effect of intensive treatment of diabetes on the development and progression of long-term complications in insulindependent diabetes mellitus. The Diabetes Control and Complications Trial Research Group. N Engl J Med 1993, 329(14):977-986.

5. United Kingdom Prospective Diabetes Study (UKPDS). 13: Relative efficacy of randomly allocated diet, sulphonylurea, insulin, or metformin in patients with newly diagnosed noninsulin dependent diabetes followed for three years. $B m j$ 1995, 310(6972):83-88.

6. Brownlee M: Biochemistry and molecular cell biology of diabetic complications. Nature 200I, 4I4(6865):8I3-820.

7. Sheetz MJ, King GL: Molecular understanding of hyperglycemia's adverse effects for diabetic complications. Jama 2002, 288(20):2579-2588.
8. Farhangkhoee $\mathrm{H}$, Khan ZA, Kaur H, Xin X, Chen S, Chakrabarti S: Vascular endothelial dysfunction in diabetic cardiomyopathy: Pathogenesis and potential treatment targets. Pharmacol Ther 2005.

9. Khan ZA, Farhangkhoee H, Chakrabarti S: Towards newer molecular targets for chronic diabetic complications. Curr Vasc Pharmacol 2006, 4(I):45-57.

10. Bonnefont-Rousselot $D$ : Glucose and reactive oxygen species. Curr Opin Clin Nutr Metab Care 2002, 5(5):56I-568.

II. Stadler K, Jenei V, von Bolcshazy G, Somogyi A, Jakus J: Increased nitric oxide levels as an early sign of premature aging in diabetes. Free Radic Biol Med 2003, 35 ( 10 ): 1240-125I.

12. Hattori R, Sase K, Eizawa H, Kosuga K, Aoyama T, Inoue R, Sasayama $S$, Kawai C, Yui Y, Miyahara K, et al.: Structure and function of nitric oxide synthases. Int J Cardiol I994, 47( ( Suppl):S7I-5.

13. Sessa WC: The nitric oxide synthase family of proteins. J Vasc Res 1994, 3 I(3): | 3 |- | 43.

14. Andrew PJ, Mayer B: Enzymatic function of nitric oxide synthases. Cardiovasc Res 1999, 43(3):52I-53I.

15. Beckman JS, Koppenol WH: Nitric oxide, superoxide, and peroxynitrite: the good, the bad, and ugly. Am J Physiol I 996, 27 I (5 Pt I):CI424-37.

16. Santilli F, Cipollone F, Mezzetti A, Chiarelli F: The role of nitric oxide in the development of diabetic angiopathy. Horm Metab Res 2004, 36(5):319-335.

17. Li H, Forstermann $\mathrm{U}$ : Nitric oxide in the pathogenesis of vascular disease. J Pathol 2000, 190(3):244-254.

18. Farhangkhoee H, Khan ZA, Mukherjee S, Cukiernik M, Barbin YP, Karmazyn M, Chakrabarti S: Heme oxygenase in diabetesinduced oxidative stress in the heart. J Mol Cell Cardiol 2003, 35( I 2): I 439-I448.

19. Ammon HP, Wahl MA: Pharmacology of Curcuma longa. Planta Med 199I, 57(I): I-7.

20. Bengmark S: Curcumin, an atoxic antioxidant and natural NFkappaB, cyclooxygenase-2, lipooxygenase, and inducible nitric oxide synthase inhibitor: a shield against acute and chronic diseases. JPEN J Parenter Enteral Nutr 2006, 30(I):45-5I.

21. Arun N, Nalini N: Efficacy of turmeric on blood sugar and polyol pathway in diabetic albino rats. Plant Foods Hum Nutr 2002, 57(I):4I-52.

22. Balasubramanyam M, Koteswari AA, Kumar RS, Monickaraj SF, Maheswari JU, Mohan V: Curcumin-induced inhibition of cellular reactive oxygen species generation: novel therapeutic implications. J Biosci 2003, 28(6):715-72I.

23. Joe B, Vijaykumar M, Lokesh BR: Biological properties of curcumin-cellular and molecular mechanisms of action. Crit Rev Food Sci Nutr 2004, 44(2):97-III.

24. Singh S, Aggarwal BB: Activation of transcription factor NFkappa $B$ is suppressed by curcumin (diferuloylmethane) [corrected]. J Biol Chem 1995, 270(42):24995-25000.

25. Cai L, Chen S, Evans T, Cherian MG, Chakrabarti S: Endothelin-Imediated alteration of metallothionein and trace metals in the liver and kidneys of chronically diabetic rats. Int J Exp Diabetes Res 2002, 3(3): 193-198.

26. Chen S, Evans T, Deng D, Cukiernik M, Chakrabarti S: Hyperhexosemia induced functional and structural changes in the kidneys: role of endothelins. Nephron 2002, 90(I):86-94.

27. Srimal RC, Dhawan BN: Pharmacology of diferuloyl methane (curcumin), a non-steroidal anti-inflammatory agent. J Pharm Pharmacol 1973, 25(6):447-452.

28. Arora RB, Kapoor V, Basu N, Jain AP: Anti-inflammatory studies on Curcuma longa (turmeric). Indian J Med Res 1971, 59(8): 1289-1295.

29. Chen S, Mukherjee S, Chakraborty C, Chakrabarti S: High glucoseinduced, endothelin-dependent fibronectin synthesis is mediated via NF-kappa B and AP-I. Am J Physiol Cell Physiol 2003, 284(2):C263-72.

30. Pendurthi UR, Williams JT, Rao LV: Inhibition of tissue factor gene activation in cultured endothelial cells by curcumin. Suppression of activation of transcription factors Egr-I, API, and NF-kappa B. Arterioscler Thromb Vasc Biol 1997, I7( I 2):3406-34I3.

3I. Mahakunakorn P, Tohda M, Murakami Y, Matsumoto K, Watanabe H, Vajaragupta O: Cytoprotective and cytotoxic effects of curcumin: dual action on $\mathrm{H} 2 \mathrm{O} 2$-induced oxidative cell damage in NG I 08-I 5 cells. Biol Pharm Bull 2003, 26(5):725-728. 
32. Farhangkhoee $H$, Khan ZA, Barbin $Y$, Chakrabarti S: Glucoseinduced up-regulation of CD36 mediates oxidative stress and microvascular endothelial cell dysfunction. Diabetologia 2005, 48(7): |40|-|4|0.

33. Khan ZA, Barbin YP, Cukiernik M, Adams PC, Chakrabarti S: Hemeoxygenase-mediated iron accumulation in the liver. Can J Physiol Pharmacol 2004, 82(7):448-456.

34. Chen S, Khan ZA, Cukiernik M, Chakrabarti S: Differential activation of NF-kappa B and AP-I in increased fibronectin synthesis in target organs of diabetic complications. Am J Physiol Endocrinol Metab 2003, 284(6):El 089-97.

35. Jay $\mathrm{D}$, Hitomi $\mathrm{H}$, Griendling $\mathrm{KK}$ : Oxidative stress and diabetic cardiovascular complications. Free Radic Biol Med 2006, 40(2): $183-192$.

36. King GL, Loeken MR: Hyperglycemia-induced oxidative stress in diabetic complications. Histochem Cell Biol 2004, I 22(4):333-338.

37. Pricci F, Leto G, Amadio L, lacobini C, Cordone S, Catalano S, Zicari A, Sorcini M, Di Mario U, Pugliese G: Oxidative stress in diabetesinduced endothelial dysfunction involvement of nitric oxide and protein kinase C. Free Radic Biol Med 2003, 35(6):683-694.

38. Aggarwal BB, Kumar A, Bharti AC: Anticancer potential of curcumin: preclinical and clinical studies. Anticancer Res 2003, 23(IA):363-398.

39. Pan MH, Lin-Shiau SY, Lin JK: Comparative studies on the suppression of nitric oxide synthase by curcumin and its hydrogenated metabolites through down-regulation of IkappaB kinase and NFkappaB activation in macrophages. Biochem Pharmacol 2000, 60(II):1665-1676.

40. Brouet I, Ohshima $\mathrm{H}$ : Curcumin, an anti-tumour promoter and anti-inflammatory agent, inhibits induction of nitric oxide synthase in activated macrophages. Biochem Biophys Res Commun 1995, 206(2):533-540.

41. Johnston BD, DeMaster EG: Suppression of nitric oxide oxidation to nitrite by curcumin is due to the sequestration of the reaction intermediate nitrogen dioxide, not nitric oxide. Nitric Oxide 2003, 8(4):231-234.

42. Quattrone S, Chiappini L, Scapagnini G, Bigazzi B, Bani D: Relaxin potentiates the expression of inducible nitric oxide synthase by endothelial cells from human umbilical vein in in vitro culture. Mol Hum Reprod 2004, I 0(5):325-330.

43. McLean M, Bowman M, Clifton V, Smith R, Grossman AB: Expression of the heme oxygenase-carbon monoxide signalling system in human placenta. J Clin Endocrinol Metab 2000, 85(6):2345-2349.
Publish with Bio Med Central and every scientist can read your work free of charge

"BioMed Central will be the most significant development for disseminating the results of biomedical research in our lifetime. "

Sir Paul Nurse, Cancer Research UK

Your research papers will be:

- available free of charge to the entire biomedical community

- peer reviewed and published immediately upon acceptance

- cited in PubMed and archived on PubMed Central

- yours - you keep the copyright
BioMedcentral 